\title{
De-Colourisation of Textile Dye Effluents using cost-effective Nigella Sativa Seed Waste
}

\author{
Raja Balasaraswathi $\mathrm{S}^{1} \mid$ Kiruba $\mathrm{T}^{2}$ \\ ${ }^{1}$ Department of Fashion Technology, PSG College of Technology, Coimbatore, Tamil Nadu, India \\ ${ }^{2}$ Department of Fashion Technology, PSG College of Technology, Coimbatore, Tamil Nadu, India
}

\section{To Cite this Article}

Raja Balasaraswathi S and Kiruba T, "De-Colourisation of Textile Dye Effluents using cost-effective Nigella Sativa Seed Waste”, International Journal for Modern Trends in Science and Technology, 6(9S): 78-82, 2020.

\section{Article Info}

Received on 25-August-2020, Revised on 08-September-2020, Accepted on 12-September-2020, Published on 18-September-2020.

\section{ABSTRACT}

The textile industry is one of the major industries contributing to water pollution. The wet processing of textiles involves the usage of a wide variety of chemicals and dyes. This water-intensive process can potentially affect the water bodies by its effluents. The treatment of dye effluents and reusing of the water could be the possible solution to reduce the impact. Adsorption is one of the most common methods used for textile effluent treatment. Various bio-adsorbents are explored to make the adsorption more sustainable. Nigella Sativa (Black cumin) seeds and its oil are having good medicinal value. The seed-waste left after the oil extraction is found to have active components that can be used as an effective bio-adsorbent. The dye removal efficiency of Nigella Sativa seed-waste is investigated under different experimental conditions (varied adsorbent dose, temperature, $\mathrm{pH}$, and contact time) for reactive dyes. The maximum removal efficiency of $91 \%$ is obtained at the optimized experimental condition. Thus the study emphasizes that the no-cost Nigella Sativa seed-waste can be used as an effective bio-adsorbent for reactive dye removal from dye effluents.

KEYWORDS: Nigella Sativa seed-waste, Dye Effluents, Adsorption, Reactive dyes, Bio-adsorbent

\section{INTRODUCTION}

One of the major reasons for the textile industry to become the world's second-largest polluting industry is the toxic chemicals and dyes used in textile processing. The fascinating colors we see in our clothing are got after processing with various toxic dyes that have the potential to create pollution in water systems. Approximately 10-15\% of dyes used in the dyeing process are released in the effluent. Nowadays, synthetic dyes are used predominantly. Synthetic dyes are made of organic compounds that are potential enough to cause detrimental effects on the environment as well as humans [1]. The dye effluent treatment grabs attention as the treatment of effluents can lead to reduce the load on the environment and to reuse the huge amount of water that is used in the processing. For the treatment of dye effluents, various physical, chemical, and biological processes are being adopted. Yet, among all these treatments, adsorption, a physical method, seems to be more effective because of its simplicity. Adsorption is a surface phenomenon [2] where a solid substance(adsorbent) can hold the particles on its surface. And hence the equipment and energy involved in the adsorption process are very less when compared with other methods. Various adsorbents are found to be effective in treating textile dye effluents. The most commonly available adsorbents are activated carbon, silica gel, and 
zeolite [3]. These adsorbents are synthetic and so the disposal of these adsorbents became tedious. Moreover, these synthetic adsorbents are not cost-effective. These drawbacks of synthetic adsorbents give rise to the search for bio-adsorbents.

Since the use of bio-adsorbent in treating textile effluents can make the process more sustainable, various studies have been made to explore different naturally occurring bio-adsorbents and their efficiency in the removal of textiles dyes. The bio-solid substances are found to have more adsorption sites which facilitate adsorption and also these sites can be modified to increase the binding energy towards the charged pollutants [4]. Some of the known bio-adsorbents are neem sawdust [5], maize cob [6], shale oil dust [7], apple peels [8]. Nigella Sativa (Black cumin) is the herb that belongs to the Ranunculaceae family [9]. Nigella Sativa seed oil has many applications including medicine, spices in meals, food flavoring [10] which leads to increased oil production and generation of seed waste. After oil extraction, the seed still contains active components that can facilitate effective adsorption [11]. This study aims to use Nigella Sativa (Black cumin) seed waste which is obtained as waste from the oil industry as a cost-effective bio-adsorbent for dye removal. Moreover, the experimental conditions such as adsorbent dose, temperature, $\mathrm{pH}$ of the solution, and contact time are optimized.

\section{MATERIALS AND METHODS}

Nigella sativa seeds are bought from a local store in Coimbatore. The seeds are powdered and crushed to remove oil content. This replicates the seed-waste obtained from the oil industry. Reactive dyes are sourced from Textile Chemical Processing Laboratory, PSG College of Technology, Coimbatore. The standard dye solution is prepared by dissolving $10 \mathrm{mg}$ of reactive dye in $100 \mathrm{~mL}$ of water to achieve a concentration of $0.1 \mathrm{~g} / \mathrm{L}$. The other known solutions that are used for Beer-Lambert's plot are prepared from the standard solution using the dilution method. The experiments are done sequentially using the result of one in the subsequent experiment. Table I shows the condition of each experiment.

The absorbance values of the treated and untreated solutions are found using a spectrophotometer and the absorbance value is used to find the concentration using Beer-Lambert's law [12]. The equation (1) is used for finding the removal efficiency [13].
Removal efficiency $(\%)=\frac{(\mathrm{Co}-\mathrm{Ce})}{\mathrm{Co}} \times 100$

Table I Experimental Conditions

\begin{tabular}{|c|c|c|}
\hline Exp & Conditions & Outcome \\
\hline \multirow{4}{*}{1} & $\begin{array}{l}\text { Adsorbent Dose: } 1 \%, 2 \% \text {, } \\
3 \%, 4 \%, 5 \%\end{array}$ & \multirow{4}{*}{$\begin{array}{c}\text { Optimum } \\
\text { Adsorbent } \\
\text { Dose }\end{array}$} \\
\hline & $\mathrm{pH}: 5$ & \\
\hline & Temp.: Room Temp. & \\
\hline & Contact time: $24 \mathrm{hrs}$ & \\
\hline \multirow{4}{*}{2} & Adsorbent Dose: Optimum & \multirow{4}{*}{$\begin{array}{l}\text { Optimum } \\
\text { pH }\end{array}$} \\
\hline & $\mathrm{pH}: 5,7,10$ & \\
\hline & Temp.: Room Temp. & \\
\hline & Contact time: $24 \mathrm{hrs}$ & \\
\hline \multirow{4}{*}{3} & Adsorbent Dose: Optimun & \multirow{4}{*}{$\begin{array}{l}\text { Optimum } \\
\text { Temp. }\end{array}$} \\
\hline & pH: Optimum & \\
\hline & Temp.: $15^{\circ} \mathrm{C}, 25^{\circ} \mathrm{C}, 40^{\circ} \mathrm{C}$ & \\
\hline & Contact time: $24 \mathrm{hrs}$ & \\
\hline \multirow{4}{*}{4} & Adsorbent Dose: Optimum & \multirow{4}{*}{$\begin{array}{c}\text { Optimum } \\
\text { Contact } \\
\text { Time }\end{array}$} \\
\hline & pH: Optimum & \\
\hline & Temp.: Optimum & \\
\hline & $\begin{array}{l}\text { Contact time: } 12 \mathrm{hrs}, 24 \mathrm{hrs} \text {, } \\
36 \mathrm{hrs}\end{array}$ & \\
\hline
\end{tabular}

The color strength of the treated solutions is also measured by the method using the light reflectance technique. Chroma (psychometric chroma) values were calculated using the following equation [14]:

$$
\mathrm{C}_{(\mathrm{ab})^{*}}=\left(\mathrm{a}^{2}+\mathrm{b}^{2}\right)^{1 / 2}, \Delta \mathrm{C}^{*}=\mathrm{C}^{*}{ }_{1(\mathrm{ab})}-\mathrm{C}^{*}{ }_{2(\mathrm{ab})}-(2)
$$

where $\mathrm{C}^{*}{ }_{1(\mathrm{ab})}$ is the chroma value for the standard sample and $\mathrm{C}^{*} 2(\mathrm{ab})$ is the chroma value for the produced sample.

\section{RESULTS AND Discussion}

\section{A. Beer Lambert's Plot}

The Beer Lambert's graph was plotted between the absorbance and concentration of 10 known solutions of different concentrations. A linear equation can be developed using the relationship between the absorbance value and the solution concentration. Table II shows the concentration of known solutions and their corresponding absorbance values measured using the spectrophotometer. 
Table II Absorbance Values of Known Solutions

\begin{tabular}{|c|c|c|}
\hline S.no & $\begin{array}{c}\text { Concentration } \\
\text { of dye in } \mathrm{g} / \mathrm{L}\end{array}$ & $\begin{array}{c}\text { Absorbance } \\
\text { Value }\end{array}$ \\
\hline 1. & 0.005 & 0.086 \\
2. & 0.00625 & 0.090 \\
3. & 0.007 & 0.096 \\
4. & 0.008 & 0.1 \\
5. & 0.01 & 0.11 \\
6. & 0.0125 & 0.121 \\
7. & 0.016 & 0.143 \\
8. & 0.025 & 0.185 \\
9. & 0.05 & 0.323 \\
10. & 0.1 & 0.528 \\
\hline
\end{tabular}

Here, the corresponding linear equation is $\mathrm{y}=$ $4.737 x+0.064$ where $y$ is the absorbance value and $\mathrm{x}$ is the concentration of the solution in $\mathrm{g} / \mathrm{L}$. With the help of the equation, dye concentrations of the sample solutions after treating with Nigella Sativa in the experiments are calculated. Fig. 1 shows the Beer Lambert's Plot.

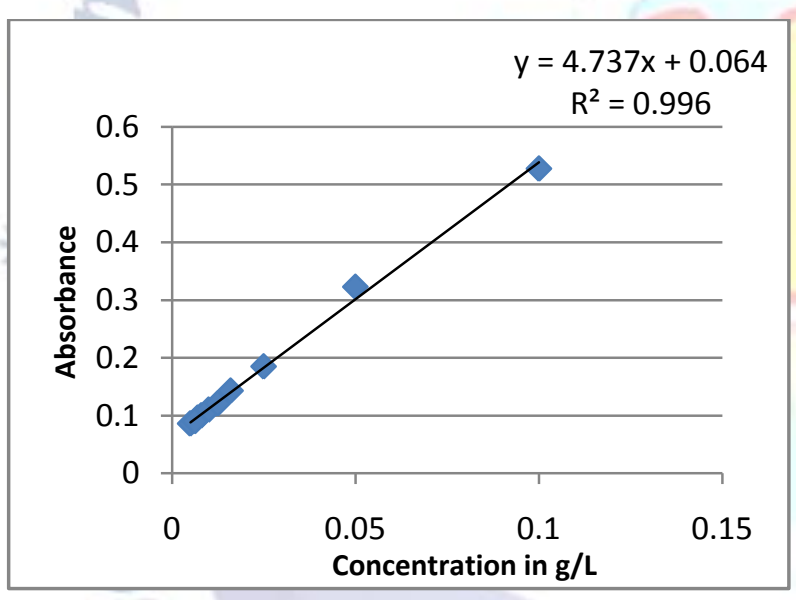

Fig. 1 Beer Lambert's Plot

\section{B. Effect of Adsorbent Dose}

The effect of adsorbent dose on the removal efficiency of the reactive dye on Nigella Sativa seed cake was investigated. The removal efficiency significantly varied with the adsorbent dose. The removal efficiency increases with an increase in adsorbent dose. The adsorption increases from $0.80 \mathrm{mg} / \mathrm{g}$ to $1.66 \mathrm{mg} / \mathrm{g}$ as increasing the adsorbent concentration from $1 \mathrm{~g} / \mathrm{L}$ to $5 \mathrm{~g} / \mathrm{L}$. A similar effect was observed in the study of adsorption of Crystal Violet, Methylene Blue, Malachite Green, and Rhodamine B dyes by neem sawdust [5]. The increase in the active adsorption sites with increased adsorbent causes more adsorption. Fig. 2shows the effect of adsorbent dose on the removal efficiency.

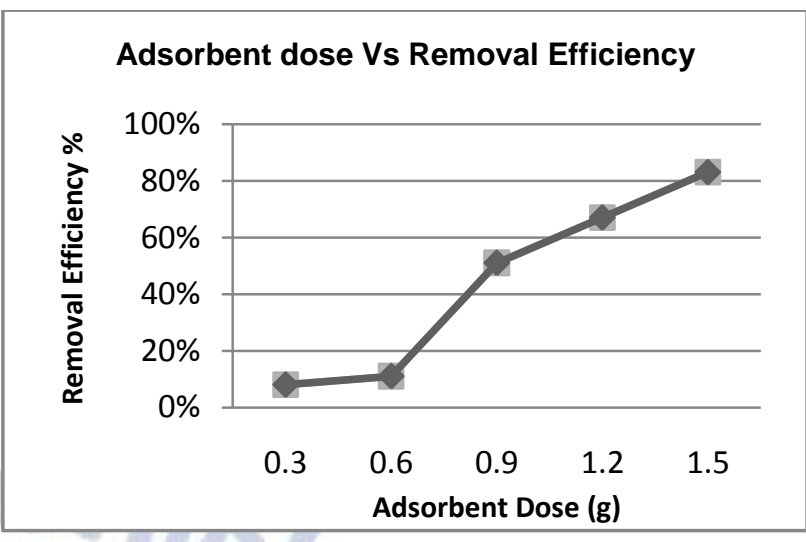

Fig. 2 Effect of Adsorbent dose

The chroma values of the treated and untreated solution also show that with increasing adsorbent dose, the color strength gets reduced. The chroma values of treated samples are shown in Table III.

\section{Effect of $p H$}

The investigation of the effect of $\mathrm{pH}$ on the adsorption level has shown that the adsorption level increases at acidic $\mathrm{pH}$. The adsorption decreases from $1.66 \mathrm{mg} / \mathrm{g}$ to $0.01 \mathrm{mg} / \mathrm{g}$ when the $\mathrm{pH}$ is changed from 5 to 10 . In acidic $\mathrm{pH}$, the solution will be dominated by positively charged particles. Reactive dyes being anionic can easily get attracted to the adsorbent at acidic $\mathrm{pH}$. This result is following the result of the study on adsorption of methylene blue using apple peels where adsorption is effective in basic $\mathrm{pH}$ which is attributed to the cationic nature of methylene blue [8]. Fig. 3 shows the effect of $\mathrm{pH}$ on the removal efficiency.

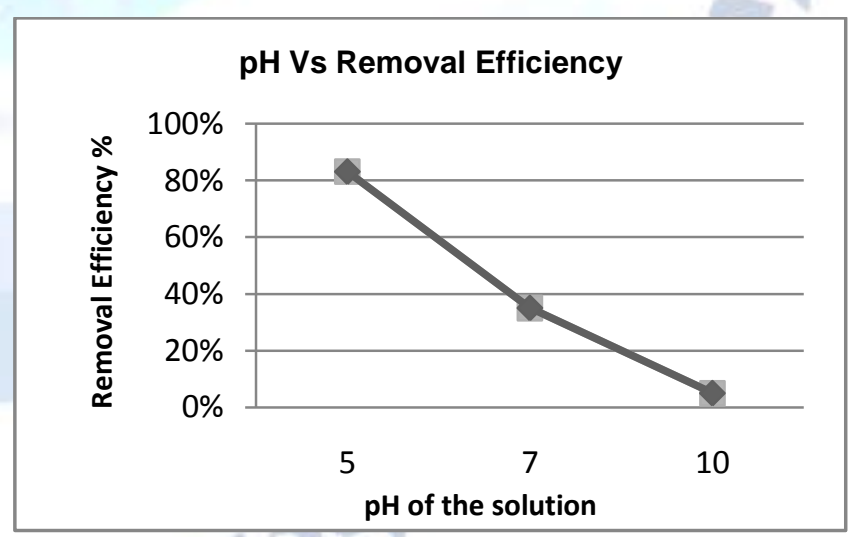

Fig. 3 Effect of $p H$

The chroma value also gets increased from 10.186 to 15.723 while increasing the $\mathrm{pH}$ from 5 to 10. Thus, acidic $\mathrm{pH}$ will be effective for the removal of reactive dyes using Nigella Sativa seed-waste.

\section{Effect of Temperature}

The variation in the temperature shows a significant difference in the adsorption level and so the removal efficiency. 


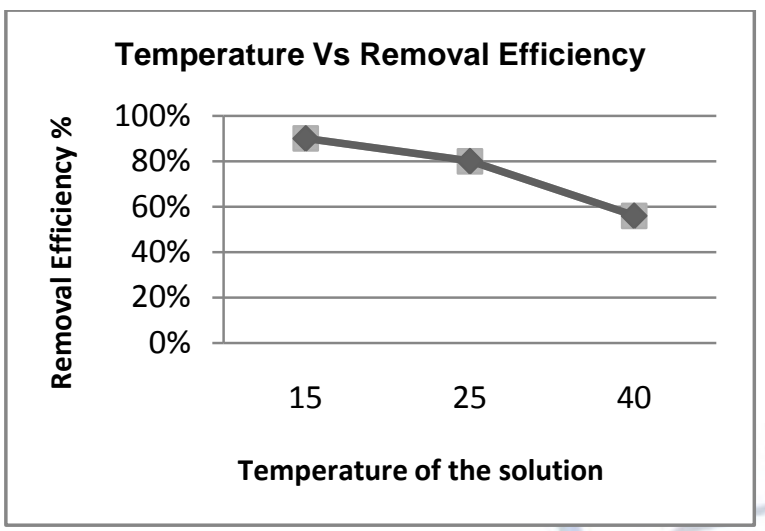

Fig. 4 Effect of Temperature

The increased removal efficiency is noted at a lower temperature. The adsorption of reactive dyes increased from $1.12 \mathrm{mg} / \mathrm{g}$ to $1.80 \mathrm{mg} / \mathrm{g}$ when the temperature is decreased from $40^{\circ} \mathrm{C}$ to $15^{\circ} \mathrm{C}$. At higher temperatures, the solubility of the adsorbent gets increased which in turn increases the energy of the particles. This leads to the desorption of the adsorbate from the adsorbent.

The decrease in the chroma values with increased temperature shows that the color strength can be reduced more at the lower temperature. The chroma values of the solutions treated at different temperatures are summarized in Table III.

Table III Removal efficiency and chroma values in different experimental conditions

\begin{tabular}{|c|c|c|c|c|c|c|}
\hline 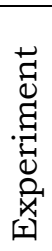 & 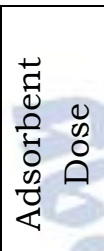 & 跑 & 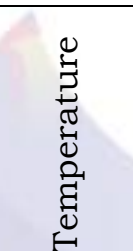 & 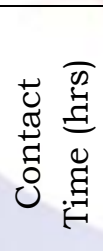 & 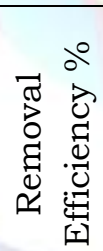 & 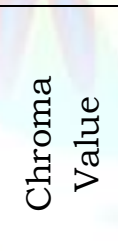 \\
\hline \multirow{5}{*}{1} & $1 \%$ & 5 & $\begin{array}{l}\text { Room } \\
\text { Temp }\end{array}$ & 24 & 8 & 19.36 \\
\hline & $2 \%$ & 5 & $\begin{array}{l}\text { Room } \\
\text { Temp }\end{array}$ & 24 & 11 & 17.65 \\
\hline & $3 \%$ & 5 & $\begin{array}{l}\text { Room } \\
\text { Temp }\end{array}$ & 24 & 51 & 14.98 \\
\hline & $4 \%$ & 5 & $\begin{array}{l}\text { Room } \\
\text { Temp }\end{array}$ & 24 & 67 & 11.72 \\
\hline & $5 \%$ & 5 & $\begin{array}{l}\text { Room } \\
\text { Temp }\end{array}$ & 24 & 83 & 10.19 \\
\hline \multirow{3}{*}{2} & $5 \%$ & 5 & $\begin{array}{l}\text { Room } \\
\text { Temp }\end{array}$ & 24 & 83 & 10.19 \\
\hline & $5 \%$ & 7 & $\begin{array}{l}\text { Room } \\
\text { Temp }\end{array}$ & 24 & 35 & 13.22 \\
\hline & $5 \%$ & 10 & $\begin{array}{l}\text { Room } \\
\text { Temp }\end{array}$ & 24 & 5 & 15.72 \\
\hline 3 & $5 \%$ & 5 & $15^{\circ} \mathrm{C}$ & 24 & 90 & 9.99 \\
\hline
\end{tabular}

\begin{tabular}{|c|c|c|c|c|c|c|}
\hline \multirow{3}{*}{4} & $5 \%$ & 5 & $25^{\circ} \mathrm{C}$ & 24 & 80 & 10.23 \\
\cline { 2 - 7 } & $5 \%$ & 5 & $40^{\circ} \mathrm{C}$ & 24 & 56 & 11.21 \\
\hline \multirow{3}{*}{4} & $5 \%$ & 5 & $15^{\circ} \mathrm{C}$ & 12 & 88 & 10.03 \\
\cline { 2 - 7 } & $5 \%$ & 5 & $15^{\circ} \mathrm{C}$ & 24 & 90 & 9.92 \\
\cline { 2 - 6 } & $5 \%$ & 5 & $15^{\circ} \mathrm{C}$ & 36 & 91 & 9.59 \\
\hline
\end{tabular}

\section{E. Effect of Contact Time}

The contact time has no significant effect on the adsorption. Though adsorption increases with an increase in contact time, the difference is not significant. The adsorption stops when all the active sites get occupied by the adsorbate and there will be no more adsorbent even the process is carried out for a longer time. Fig. 5 shows the effect of the contact time of adsorption. The chroma values of samples treated for the different duration shown in table 3 are also not varied significantly. This again confirms that there is no significant change in color strength.

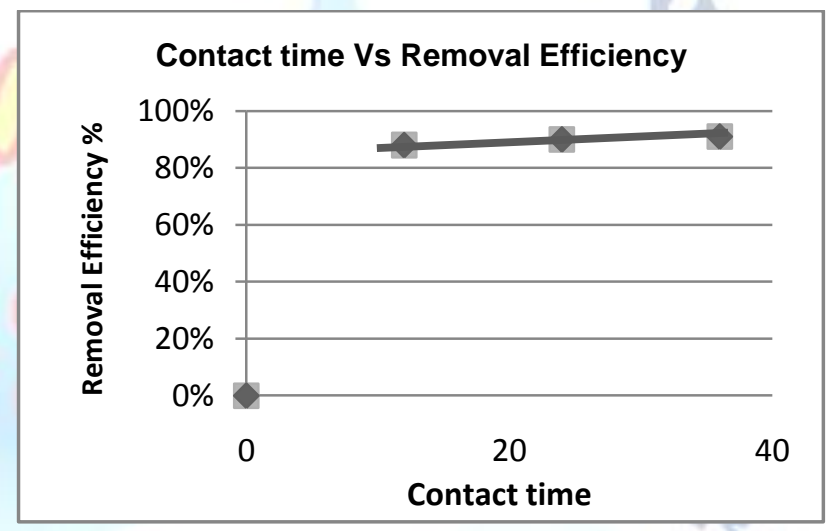

Fig. 5 Effect of Contact Time

Table IV The comparison of Nigella Sativa Seed-waste with other bio-adsorbents for reactive dye removal

\begin{tabular}{|c|c|c|}
\hline Bio-Adsorbent & $\begin{array}{c}\text { Max. Removal } \\
\text { Efficiency }\end{array}$ & Reference \\
\hline $\begin{array}{c}\text { Nigella Sativa } \\
\text { Seed-waste }\end{array}$ & $91 \%$ & This study \\
\hline Aman Husk & $96 \%$ & {$[15]$} \\
\hline Cotton dust & $98.5 \%$ & {$[16]$} \\
\hline Kenaf Core Fiber & $99.65 \%$ & {$[17]$} \\
\hline
\end{tabular}

\section{Conclusion}

It has been described that the Nigella Sativa (Black Cumin) seed-waste can be used as a potential bio-adsorbent for the removal of reactive dyes from the textile dye effluents. With the studied experimental conditions, the maximum removal efficiency of $91 \%$ is achieved. The investigation of different experimental conditions has shown that 
the increased adsorbent dose, acidic $\mathrm{pH}$, lower temperature favors the adsorption of reactive dyes using Nigella sativa seed-waste. Though the contact time has no significant effect on the adsorption, it can affect the processing time. Hence, further study has to be made on the effect of contact time to find the minimum time at which the adsorption can be maximum. This would reduce the processing time.

\section{ACKNOWLEDGMENT}

Theauthors would like to gratefully acknowledge Dr. R. Rathinamoorthy, Associate Professor, PSG College of Technology, Coimbatore, India for his guidance in completing the work. The authors also thank PSG College of Technology, Coimbatore for providing all the facilities to accomplish this work.

\section{REFERENCES}

[1] Mohamed A. Hassaan, Ahmed El Nemr. Health and Environmental Impacts of Dyes: Mini Review. American Journal of Environmental Science and Engineering. Vol. 1, No. 3, 2017, pp. 64-67.

[2] Renge,V.C., Khedkar,S.V., Pande,S.V.,(2012) Removal of Heavy Metals From Wastewater Using Low Cost Adsorbents : A Review. Scientific Reviews and Chemical Communications, 2 (4), 580-584.

[3] Sahu,O., Singh,N.,(2018). Significance of bioadsorption process on textile industry wastewater In S.Islam, B.S.Butola,(Eds.), The Impact and Prospects of Green Chemistry for Textile Technology (pp.367-416) Woodhead Publishing

[4] Siddiqui, S.I., Zohra, F., Chaudhry, S.A., Nigella sativa seed based nanohybrid composite-Fe2O3-SnO2/BC: A novel material for enhanced adsorptive removal of methylene blue from water, Environmental Research (2019), doi: https://doi.org/10.1016/ j.envres.2019.108667

[5] Khattri,S.D., Singh,M.K. (2000). Colour removal from synthetic dye wastewater using a bioadsorbent.Water, Air, and Soil Pollution 120, 283-294

[6] El-Geundi,M. (1991) Colour removal from textile effluents by adsorption Techniques. Water research, 25 (3), 271-273.

[7] Zhao,Z., Yuan, Meng Fu, La Su, Zhaohui Li (2014) Removal Of Methylene Blue From Aqueous Solution By Using Oil Shale Ash. Oil Shale, 31 (2), 161-173

[8] Enniya,I., Jourani,A., (2017) Study of Methylene Blue Removal by a biosorbent prepared with Apple peels. Journal of Materials and Environmental Science, 8 (12), 4573-4581

[9] Iftekhar,S., Ramasamy,D.L., Srivastava,V., Asif,M.B., Sillanpää,M.,(2018). Understanding the factors affecting the adsorption of Lanthanum using different adsorbents: A critical review. Chemosphere, 204, 413-430

[10] Hassanien,M.F.R., Assiri,A.M.A., Alzohairy,A.M., Oraby,H.F. (2015) Health-promoting value and food applications of black cumin essential oil: an overview, Journal of Food Science and Technology, DOI: $10.1007 / \mathrm{s} 13197-015-1785-4$

[11] Thilakarathna,RCN., Madhusankha,GDMP., Navaratne,SB., (2018) Comparison of physico-chemical properties of Indian and Ethiopian origin Black cumin
(Nigella sativa) seed cake. International Journal of Food Science and Nutrition, 3 (4), 30-31

[12] Schneider, R. F. Chemistry 133 webpage, Beer's Law Description,

http://www.ic.sunysb.edu/Class/che133/lectures/beers1 aw.html accessed March 15, 2020.

[13] Taha, D,N., Samaka, I.S., Mohammed, L.A., (2013), Adsorptive Removal of Dye from Industrial Effluents Using Natural Iraqi Palygorskite Clay As Low-Cost Adsorbent, Journal of Asian Scientific Research, 3(9):945-955. http://aessweb.com/journal-detail.php?id=5003

[14] Prathiba Devi,R., Rathinamoorthy, R., Jeyakodi, J., (2013), Effect of Jute Proportion on the Color Strength Value of Jute/Cotton Union Fabric, International Journal of Engineering Research, Volume No.2, Issue No. 4, pp : 294-299.

[15] Khalque, A., Ahamed, S.S., Khan, S.A., Awual, R., Islam, E., and Rahman, L., (2018), Utilizing Aman husk for efficient removal of reactive dyes from industrial wastewater, Global Journal for research analysis, Vol. 7, No. 2.

[16] Khalque, A., Ahamed, S.S., Khan, S.A., Rabbani, K.A., Islam, E., Alam, S.,(2018), Reactive Dye Removal From Industrial Wastewater On Cotton Dust As A Bio Adsorbent, International Journal of Scientific \& Technology Research, Vol. 7, No.9

[17] Idan, I.J., Abdullah, L.C., Choong, T.S.Y., Jamil, S.N.A., (2018) Equilibrium, kinetics and thermodynamic adsorption studies of acid dyes on adsorbent developed from kenaf core fiber,Adsorption Science and Technology, Vol. 36, pp. 694-712. 